\title{
The taxonomic status of Porites sverdrupi, an endemic coral of the Gulf of California
}

\section{Posición taxonómica de Porites sverdrupi, coral endémico del Golfo de California}

\author{
R. Andrés López-Pérez ${ }^{1 \%}$ \\ Héctor Reyes-Bonilla ${ }^{2}$ \\ Ann F. Budd ${ }^{3}$ \\ Francisco Correa-Sandoval ${ }^{4}$ \\ ${ }^{1}$ Instituto de Recursos \\ Universidad del Mar \\ Puerto Ángel, Oaxaca, México \\ *E-mail: rlopezpe@blue.weeg.uiowa.edu \\ ${ }^{2}$ Departamento de Biología Marina \\ Universidad Autónoma de Baja California Sur \\ La Paz, Baja California Sur CP 23080, México \\ ${ }^{3}$ Department of Geoscience \\ University of Iowa \\ Iowa City, IA 52242, USA \\ ${ }^{4}$ Instituto de Investigaciones Oceanológicas \\ Universidad Autónoma de Baja California \\ Apartado postal 453 \\ Ensenada, CP 22800, Baja California, México
}

Recibido en junio de 2003; aceptado en septiembre de 2003

\begin{abstract}
Porites sverdrupi has long been considered to be an ecotype of the more abundant and widespread species $P$. panamensis, but multivariate comparisons of corallite characteristics indicate that $P$. sverdrupi is morphologically distinct and thus represents a valid species. In these analyses, linear measurements and counts were made on 72 colonies of the two species (53 of $P$. panamensis and 19 of $P$. sverdrupi), and analyzed multivariately using canonical discriminant analysis. Generally, corallite characteristics of $P$. sverdrupi are larger in size than $P$. panamensis. Important characters in the discriminant function (e.g., number of bifurcate septa, wall thickness, and dorsal septum length) have not been recognized in previous studies of Porites in either the Indo-Pacific or Atlantic regions as being significant in distinguishing among poritid species. In addition to corallite characteristics, P. sverdrupi is unique in its ecological habit, colony form, and geographic distribution.
\end{abstract}

Key words: Porites sverdrupi, corals, Mexico, morphometrics, Scleractinia

\section{Resumen}

Desde mediados del siglo pasado Porites sverdrupi ha sido considerado como ecotipo y, por consiguiente, sinónimo de otra especie muy abundante y de amplia distribución, P. panamensis. Sin embargo, comparaciones morfométricas a nivel corallite demuestran que las colonias de $P$. sverdrupi son morfológicamente distintas y por lo tanto ésta constituye una especie válida. En este análisis se contaron o midieron 16 caracteres morfológicos en 72 colonias (53 de P. panamensis y 19 de $P$. sverdrupi) y luego fueron sometidos a un análisis discriminante. Generalmente las estructuras medidas en ambas especies se encuentran mejor desarrolladas en $P$. sverdrupi que en P. panamensis. Varios de los caracteres con mayor peso en las funciones discriminantes (e.g., número de septos bifurcados, amplitud de la pared del corallite y longitud del septo dorsal) no habían sido previamente identificados como importantes, ni en el Indo-Pacífico ni en la región del Atlántico, para el reconocimiento de especies de Porites. Además de las diferencias a nivel corallite entre ambas especies, $P$. sverdrupi es única en sus características ecológicas, forma colonial y distribución geográfica.

Palabras clave: Porites sverdrupi, corales, México, morfometría, Scleractinia

\footnotetext{
${ }^{\text {a }}$ Current address: Department of Geoscience, The University of Iowa, Iowa City, IA 52242, USA.
} 


\section{Introduction}

The presence of recent species of Porites in the eastern Pacific was first recognized in the 1900s by Grewingk (1848), who recorded a specimen from Isla del Carmen in the Gulf of California; however, it was not until Verrill's monographs (Verrill, 1864, 1866, 1868-1870) that significant advances were made in our knowledge of the systematics of the genus in this region. Today, a total of 14 nominal species of Porites are recognized in the eastern Pacific, but only 9 are considered valid (Reyes-Bonilla, 2002): P. arnaudi Reyes-Bonilla and Carricart-Ganivet, 2000; P. australiensis Vaughan, 1918; P. baueri Squires, 1959; P. lobata Dana, 1848; P. lichen Dana, 1846; P. lutea Milne Edwards and Haime, 1860; P. panamensis Verrill, 1866; P. sverdrupi Durham, 1947; and P. rus Forskaal, 1775 (Glynn, 1997; Reyes-Bonilla, 2002). Except for P. rus, all of them occur in the Mexican Pacific (Reyes-Bonilla and López-Pérez, 1998; Reyes-Bonilla and Carricart-Ganivet, 2000). The taxonomy of this genus in the eastern Pacific region is based mainly on gross colony morphology (e.g., Durham and Barnard, 1952; Brusca, 1980; Hodgson, 1995). Although this approach is fast and inexpensive, it is relatively imprecise because colony morphology in this genus varies significantly in response to environmental factors (Brakel, 1977; Foster, 1979a, 1984; Ayre et al., 1991; Knowlton et al., 1992; Potts et al., 1993; Garthwaite et al., 1994; Veron, 1995).

The taxonomy of Porites has been influenced by both "splitting" and "lumping". Initially, due to a lack of knowledge about intra-specific and inter-specific morphologic variation and the common practice of classifying every morph as a new and distinct species, several "species" were recognized and formally described. This tendency was displayed by Verrill (1864, 1866, 1868-1870) and Bernard (1905), and also in later works (Durham, 1947; Durham and Barnard, 1952; Brusca, 1980). At the other extreme, many nominal species were considered to be ecotypes and synonyms of other more abundant and widespread species (Squires, 1959; Wells, 1983), even after they were demonstrated to be genetically distinct and biologically valid (Ayre et al., 1991; Knowlton et al., 1992; Potts et al., 1993; Garthwaite et al., 1994).

The species Porites sverdrupi Durham, 1947, appears to be a victim of the practice of taxonomic lumping. First recorded and described by Durham (1947) from material in the Gulf of California, it was subsequently synonymized with Porites panamensis Verrill, 1866, by Squires (1959), who considered it a deeper-water ecomorph of $P$. panamensis (identified under its synonym, $P$. californica Verrill, 1870), based on gross corallite comparison and the apparent absence of the former at depths less than $20 \mathrm{~m}$. Other authors have suggested that $P$. sverdrupi is a valid species because it can be differentiated from $P$. panamensis in colony morphology and calicular characters (Durham, 1947; Reyes-Bonilla, 1992). In this paper, no redescription of $P$. sverdrupi and P. panamensis is attempted because both of them have already been extensively described by Durham (1947) and Verrill (1866), respectively. Instead, the

\section{Introducción}

La primera mención a la ocurrencia de especies modernas de Porites en el Pacífico oriental fue hecha por Grewingk (1848), quien encontró un espécimen en Isla del Carmen en el Golfo de California. Sin embargo, no fue sino hasta la publicación de las extensas monografías de Verrill $(1864,1866,1868$ 1870) que se pudo avanzar en el conocimiento sistemático del género en la región. En la actualidad se ha reconocido la presencia de 14 especies nominales de Porites en el Pacífico oriental, aunque sólo nueve de ellas son consideradas válidas (Reyes-Bonilla, 2002): P. arnaudi Reyes-Bonilla y CarricartGanivet, 2000; P. australiensis Vaughan, 1918; P. baueri Squires, 1959; P. lobata Dana, 1848; P. lichen Dana, 1846; $P$. lutea Milne Edwards y Haime, 1860; P. panamensis Verrill, 1866; P. sverdrupi Durham, 1947 y P. rus Forskaal, 1775 (Glynn, 1997; Reyes-Bonilla, 2002). Con excepción de P. rus, el resto de las especies han sido registradas en el Pacífico mexicano (Reyes-Bonilla y López-Pérez, 1998; Reyes-Bonilla y Carricart-Ganivet, 2000). La taxonomía de este género en el Pacífico oriental se ha basado en la morfología colonial (e.g., Durham y Barnard, 1952; Brusca, 1980; Hodgson, 1995). Aunque esta técnica de identificación es rápida y barata, también es relativamente imprecisa debido a que la morfología colonial de este género varía ampliamente en respuesta a factores ambientales (Brakel, 1977; Foster, 1979a, 1984; Ayre et al. 1991; Knowlton et al. 1992; Potts et al. 1993; Garthwaite et al. 1994; Veron 1995).

La taxonomía de Porites ha estado influenciada por la "fusión" o "separación" de especies. Al principio, debido al desconocimiento acerca de la variación morfológica a nivel intra e inter específico, y a la practica común de describir cada variación morfológica como una especie distinta, se reconocieron varias "especies" que fueron formalmente descritas. Esta práctica fue evidente en los trabajos realizados por Verrill (1864, 1866, 1868-1870) y Bernard (1905) pero también en trabajos más recientes (Durham, 1947; Durham y Barnard, 1952; Brusca, 1980). En el otro extremo, muchas especies válidas fueron consideradas ecotipos y, por consiguiente, sinónimos de especies más abundantes y de amplia distribución (Squires, 1959; Wells, 1983), aunque más adelante se demostró que éstas eran genéticamente distintas y biológicamente válidas (Ayre et al., 1991; Knowlton et al., 1992; Potts et al., 1993; Garthwaite et al., 1994).

Porites sverdrupi Durham, 1947, fue víctima de la "fusión" de especies. Esta especie fue registrada y descrita por Durham (1947) a partir de material colectado en el Golfo de California, aunque posteriormente fue sinonimizada con Porites panamensis Verrill, 1866, por Squires (1959), quien consideró a $P$. sverdrupi como el ecomorfo de agua profunda de $P$. panamensis; tal sinonimia se basó en la semejanza a nivel corallite entre ambas especies y en la aparente ausencia de $P$. sverdrupi a profundidades menores de $20 \mathrm{~m}$. Otros autores han sugerido que $P$. sverdrupi es una especie válida que puede ser 
objective of this paper is to perform a phenetic corallite-level analysis of $P$. sverdrupi and $P$. panamensis in order to compare them and clarify whether the former is a valid species. The basic hypothesis behind corallite-level comparison is the knowledge that colony morphology is highly variable in response to environmental factors (Foster, 1984; Garthwaite et al., 1994; Veron, 1995), whereas corallite architecture is mainly genetically controlled (Brakel, 1977; Foster, 1979a, 1984; Ayre et al., 1991; Knowlton et al., 1992; Potts et al., 1993; Garthwaite et al., 1994; Veron, 1995).

\section{Material and methods}

Specimens for this study were collected at various depths (0 to $30 \mathrm{~m}$ ) from Bahía de los Ángeles $\left(28^{\circ} 55^{\prime} \mathrm{N}\right)$ to Bahía Chileno $\left(22^{\circ} 56^{\prime} \mathrm{N}\right)$, in the Gulf of California (fig. 1); 53 specimens corresponded to the morphology of $P$. panamensis and 19 to $P$. sverdrupi. The type specimens of $P$. sverdrupi (USNM M547362), P. panamensis (YPM 585), P. californica (YPM 1599), P. nodulosa Verrill, 1870 (YPM 6844a), and $P$. porosa Verrill, 1870 (YPM 4068) were also included in the analysis. The differences in the number of colonies under study were due to relative abundances of the two species in the field; whereas $P$. panamensis is very abundant in the gulf, $P$. sverdrupi is scarce. In fact, Reyes-Bonilla (2002) considers it a species on the verge of natural extinction. All samples were deposited in the Museo de Historia Natural de la Universidad Autónoma de Baja California Sur (MHNUABCS) at La Paz, Mexico.

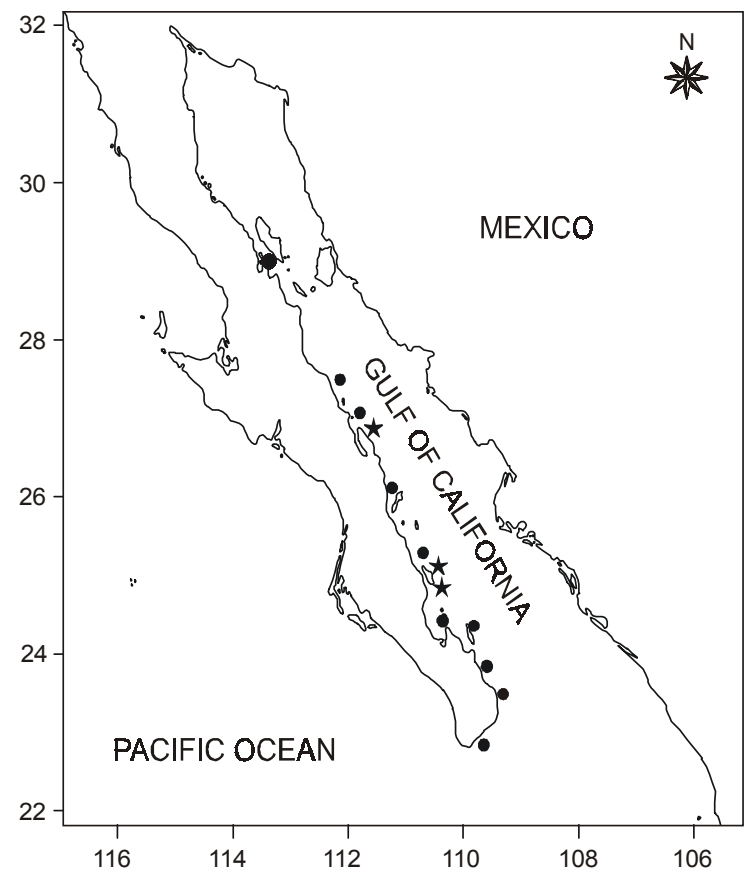

Figure 1. Sites sampled forf Porites panamensis $(\bullet)$ and $P$. sverdrupi $(\star)$ in the Gulf of California, Mexico

Figura 1. Stios de muestreo de Porites panamensis $(\bullet)$ y $P$. sverdrupi $(\star)$ en el Golfo de California, México. distinguida de $P$. panamensis con base en su morfología colonial y a los caracteres del corallite (Durham, 1947; ReyesBonilla, 1992). En la presente contribución no se realizará una redescripción de $P$. sverdrupi y $P$. panamensis debido a que ambas especies fueron descritas ampliamente por Durham (1947) y Verrill (1866), respectivamente. Por el contrario, el objetivo del presente trabajo es realizar un análisis morfológico de $P$. sverdrupi y P. panamensis, a nivel corallite, con el fin de comparar las especies y esclarecer si $P$. sverdrupi es una especie válida. La hipótesis para realizar la comparación a nivel corallite se basa en que la morfología colonial es altamente variable en respuesta a factores ambientales (Foster, 1984; Garthwaite et al., 1994; Veron, 1995), mientras que la morfología del corallite esta controlada genéticamente (Brakel, 1977; Foster, 1979a, 1984; Ayre et al. 1991; Knowlton et al. 1992; Potts et al. 1993; Garthwaite et al. 1994; Veron 1995).

\section{Material y métodos}

Las colonias utilizadas en el presente estudio fueron recolectadas a distintas profundidades (0-30 m) entre Bahía de Los Ángeles $\left(28^{\circ} 55^{\prime} \mathrm{N}\right)$ y Bahía Chileno $\left(22^{\circ} 56^{\prime} \mathrm{N}\right)$, en el Golfo de California (fig. 1); 53 colonias correspondieron a la forma de $P$. panamensis y 19 a la de $P$. sverdrupi. También se incluyeron en el análisis los especímenes tipo de $P$. sverdrupi (USNM M547362), P. panamensis (YPM 585), P. californica (YPM 1599), P. nodulosa Verrill, 1870 (YPM 6844a) y P. porosa Verrill, 1870 (YPM 4068). La diferencia en el número de colonias estudiadas de cada especie fue debida a la abundancia relativa de cada una de ellas, ya que mientras que P. panamensis es muy abundante en el Golfo, $P$. sverdrupi es escasa. De hecho, Reyes-Bonilla (2002) considera a P. sverdrupi como una especie que de forma natural se encuentra en peligro de extinción. Todos los especímenes colectados fueron depositados en el Museo de Historia Natural de la Universidad Autónoma de Baja California Sur, en La Paz, México.

\section{Estructuras del corallite y procedimientos estadísticos}

Los caracteres medidos consistieron en 16 estructuras que fueron contadas o medidas en cada corallite (tabla 1). Varias de estas estructuras (e.g., desarrollo de los septos, diámetro del corallite y grosor de la pared) fueron usadas por Brakel (1977), Foster (1986), Weil (1992) y Jameson (1997), para diferenciar especies fósiles y recientes de Porites del Atlántico occidental. Otras características (e.g., número de pali y grado de desarrollo de la columella) son caracteres diagnósticos que han sido utilizados para identificar especies de Porites tanto en el Atlántico como en el Indo-Pacífico (Brakel, 1977; Veron y Pichon, 1982, Foster, 1986; Weil, 1992).

Se midieron ocho corallites maduros en distintas posiciones dentro de la colonia, con una precisión de $0.01 \mathrm{~mm}$, usando un microscopio estereoscópico (Foster, 1985), mientras que los análisis estadísticos se realizaron utilizando el promedio de 


\section{Corallite characters and statistical procedures}

The characters consist of 16 counts and linear measurements made per corallite (table 1). Several of those (e.g., septum development, corallite diameter, and wall thickness) were used by Brakel (1977), Foster (1986), Weil (1992), and Jameson (1997) to distinguish fossil and recent species of Porites from the western Atlantic. Others (e.g., number of pali and degree of development of the columella) are diagnostic characteristics that have been used to identify Atlantic and Indo-Pacific poritid species (Brakel, 1977; Veron and Pichon, 1982; Foster, 1986; Weil, 1992).

Eight mature corallites from different positions within each colony were measured to the nearest $0.01 \mathrm{~mm}$ using a stereoscopic microscope (Foster, 1985), and statistical analyses were performed using colony means. As the major criterion to distinguish between $P$. panamensis and $P$. sverdrupi is colony shape (Durham, 1947), this was considered the main criterion to assign specimens to the a priori group (i.e., massive $=P$. panamensis [fig. 2] vs branching $=P$. sverdrupi $[$ fig. 3]). Once the colonies were assigned to the respective group, the method of Foster (1984) was applied to distinguish species. The method basically consists of evaluating colony means using discriminant analyses. The groups must be distinct at a significance level of $P<0.0001$ in order to be considered true species (Budd and Coates, 1992).

Univariate statistical analyses (Mann-Whitney U test) were run to test for differences between measured characters (Zar, 1996), using a $P$ value of 0.05 .

Table 1. List of the 16 characters and their abbreviations measured in Porites. Eight corallites were measured per colony (after Foster, 1986).

Tabla 1. Lista de los 16 caracteres que fueron medidos en Porites y sus abreviaturas. Se midieron ocho corallites por colonia (Foster, 1986).

\begin{tabular}{lc}
\hline Character & Abbreviation \\
\hline 1. Corallite diameter & $\mathrm{CD}$ \\
2. Corallite spacing & $\mathrm{CS}$ \\
3. Septum length (dorsal) & $\mathrm{L} 1$ \\
4. Septum length (ventral) & $\mathrm{L} 2$ \\
5. Septum length (lateral) & $\mathrm{L} 3$ \\
6. Number of neighboring corallites & $\mathrm{NN}$ \\
7. Number of septa & $\mathrm{NS}$ \\
8. Number of bifurcate septa & $\mathrm{NB}$ \\
9. Number of pali & $\mathrm{PL}$ \\
10. Septum thickness (dorsal) & $\mathrm{T} 1$ \\
11. Septum thickness (ventral) & $\mathrm{T} 2$ \\
12. Septum thickness (lateral) & $\mathrm{T} 3$ \\
13. Columella tubercle length & $\mathrm{C} 1$ \\
14. Columella tubercle width & $\mathrm{C} 2$ \\
15. Distance across columellar ring & $\mathrm{CW}$ \\
16. Wall thickness & $\mathrm{WT}$ \\
\hline
\end{tabular}

cada carácter para cada colonia. Como el principal criterio para distinguir entre $P$. panamensis y $P$. sverdrupi es la forma de la colonia (Durham, 1947), esta característica fue considerada para la asignación de los especímenes a cada uno de los grupos (i.e., masivo $=P$. panamensis [fig. 2] $v$ s. ramificado $=P$. sverdrupi [fig. 3]). Luego de que las colonias fueron asignadas a su respectivo grupo, se aplicó el método propuesto por Foster (1984) para distinguir entre especies. El método básicamente consiste en evaluar el promedio de cada carácter para cada colonia usando análisis discriminante. A este respecto, para que los grupos sean considerados como especies verdaderas, éstos deberán de ser distintos a un nivel de significancia de $P<0.0001$ (Budd y Coates, 1992).

Para detectar diferencias entre los caracteres medidos se utilizaron análisis estadísticos univariados (prueba U de MannWhitney) usando un valor de $P$ de 0.05 (Zar, 1996).
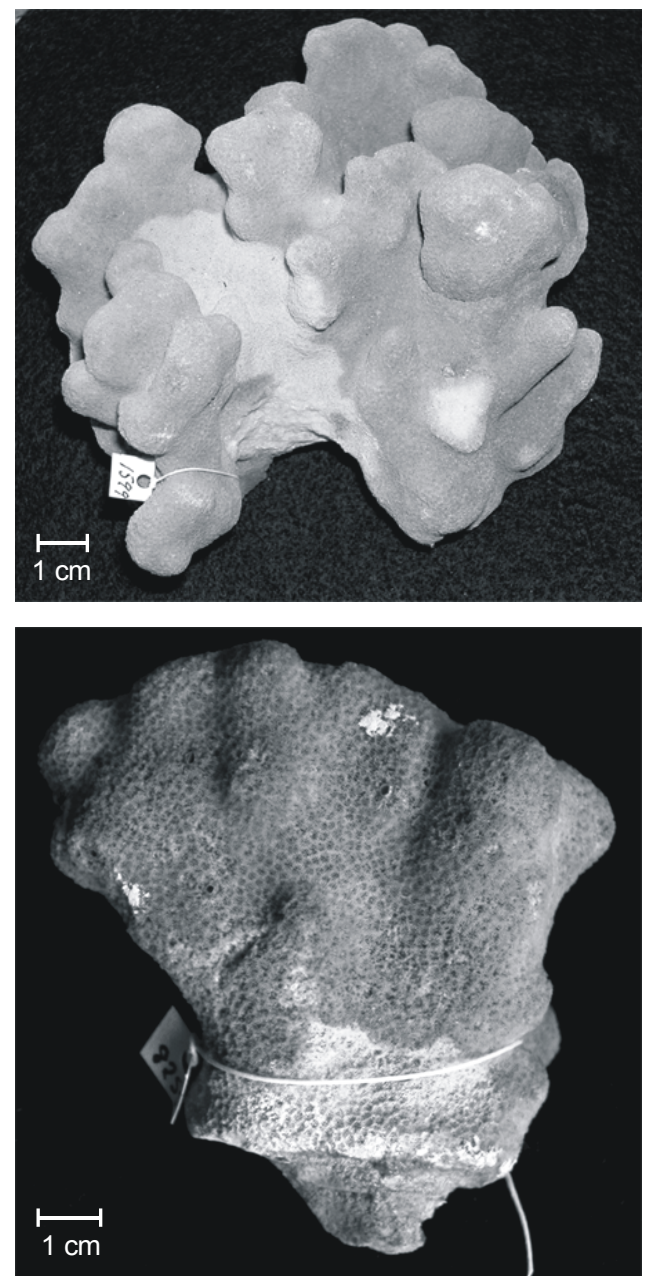

Figure 2. Porites panamensis colony. Above: P. californica type YPM 1599 Recent, La Paz, Baja California Sur, Mexico. Below: P. panamensis type 585 Recent, Isla Perla, Gulf of Panama. Note the rippled surface of YPM 585 and the short and rounded columnar expansions in the tips of YPM 1599.

Figure 2. Colonia de Porites panamensis. Arriba: P. californica tipo YPM 1599 Reciente, La Paz, Baja California Sur, México. Abajo: P. panamensis tipo YPM 585. Reciente, Isla Perla, Golfo de Panamá, Panamá. Observe la superficie ondulada de YPM 585 y las expansiones columnares, cortas y redondeadas en las puntas en YPM 1599. 


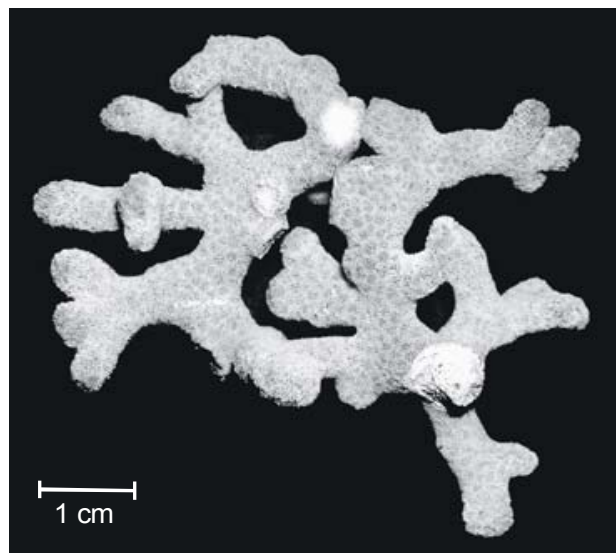

Figure 3. Porites sverdrupi colony. USNM: M547362. Recent, Bahía Salinas, Isla del Carmen, Gulf of California, Mexico. Note the profusely branched shape of the colony.

Figura 3. Colonia de Porites sverdrupi. USNM: M547362. Reciente, Bahía Salinas, Isla del Carmen, Golfo de California, México. Observe la forma altamente ramificada de la colonia.

\section{Results and discussion}

\section{Morphological variation}

Based on the discriminant analysis (fig. 4; table 2), we recognized two distinct groups that correspond to $P$. panamensis and $P$. sverdrupi, with $90.56 \%$ and $89.47 \%$ of all colonies correctly classified. One canonical variable was calculated, and the number of bifurcate septa (NB) was most heavily weighted in the function (table 2). The morphologic differences between the two groups are large enough to statistically consider each one a distinct species (Wilks' lambda $=0.4067 ; F(16,55)=$ 5.014; $P<0.000004)$, although both overlap in a small area (fig. 4). The occurrence of similar taxonomic characters and/or overlap is common in Porites species, as shown by morphometric comparisons previously done by Brakel (1977), Foster (1986), Weil (1992), and Jameson (1997) for the Porites species in the western Atlantic. This overlap is not necessarily produced by closeness in phylogeny (Weil, 1992; Potts et al., 1993; Garthwaite et al., 1994); for example, Atlantic $P$. colonensis Zlatarski, 1990 is more closely related genetically to $P$. astreoides Lamarck, 1816, but it is morphologically closer to $P$. branneri Rathbun, 1887 . The other option is that the morphological similarity between the studied species results from morphologic variation in response to environmental conditions, a phenomenon displayed not only in Porites but also in many Scleractinia (Brakel, 1977; Foster, 1979b, 1980a, b; Lasker, 1981; Budd, 1988, 1993; Weil, 1992; Budd and Coates, 1992; Amaral, 1994; Jameson, 1997).

Univariate analyses of 16 characters show that 10 characters are generally larger in $P$. sverdrupi than in P. panamensis, but meaningful differences exist in only 7 (table 3; fig. 5). Porites sverdrupi has a larger corallite diameter (CD; fig. 5a) and better developed septa (L1, L2, L3, T1, T2, T3; table 3; fig. 3b-d, f) than P. panamensis; also, the number of bifurcate

\section{Resultados y discusión}

\section{Variación morfológica}

De acuerdo al análisis discriminante (fig. 4; tabla 2) se reconocieron dos grupos que corresponden a $P$. panamensis y a P. sverdrupi, con un $90.56 \%$ y $89.47 \%$ de las colonias correctamente clasificadas. Se calculó una variable canónica, y fue el número de septos bifurcados (NB) el que mayor peso tuvo en la variable (tabla 2). Las diferencias morfológicas entre ambos grupos fueron lo suficientemente grandes para considerar a cada uno de ellos como especies distintas (Lambda de Wilks = $0.4067 ; F(16,55)=5.014 ; P<0.000004)$, no obstante existe un traslape evidente entre ambos grupos (fig. 4). La ocurrencia de caracteres taxonómicos similares y/o el traslape entre especies de Porites es común, como ha sido demostrado previamente por Brakel (1977), Foster (1986), Weil (1992), y Jameson (1997) en especies de Porites del Atlántico occidental. Dicho traslape no necesariamente es producido por una relación filogenética estrecha (Weil, 1992; Potts et al., 1993; Garthwaite et al., 1994); por ejemplo, la especie P. colonensis Zlatarski, 1990 del Atlántico está más relacionada genéticamente con $P$. astreoides Lamarck, 1816, pero morfológicamente es más afín a $P$. branneri Rathbun, 1887. La similaridad morfológica entre especies también puede ser resultado de fenotipos similares en respuesta a condiciones ambientales semejantes, fenómeno no solamente registrado en Porites sino en varios miembros del orden Scleractinia (Brakel, 1977; Foster, 1979b, 1980a, 1980b; Lasker, 1981; Budd, 1988, 1993; Weil, 1992; Budd y Coates, 1992; Amaral, 1994; Jameson, 1997).

El análisis estadístico de las 16 características morfológicas demostró que 10 de ellas se encuentran generalmente más desarrolladas en $P$. sverdrupi que en $P$. panamensis, pero sólo en siete de ellas se encontraron diferencias significativas (tabla 3; fig. 5). Porites sverdrupi posee un corallite de mayor diámetro (CD; fig. 5a) y con septos más desarrollados (L1, L2, L3, T1, T2, T3; tabla 3; fig. 3b-d, f) que P. panamensis; además, su número de septos bifurcados es mayor (NB; fig. 5e). En el Atlántico occidental esta característica ha sido asociada con un decremento en la calcificación más que con la división de las trabéculas (Foster, 1986), característica a la que Durham (1947) se refirió como "perforaciones abundantes". No obstante, debido a su importancia en el análisis discriminante (tabla 2), esta característica posee valor taxonómico y es probable que sea el caracter más importante para diferenciar entre especies de Porites en el Pacífico mexicano. El único caracter que está más desarrollado en $P$. panamensis que en $P$. sverdrupi es el grosor de la pared (WT; fig. $5 \mathrm{~g}$ ).

Respecto al resto de los caracteres $P$. panamensis presenta mayor variación morfológica que $P$. sverdrupi. Por ejemplo, $P$. panamensis usualmente posee cinco pali, pero su número puede variar entre dos y siete. Con respecto a los septos, ambas especies poseen dos ciclos compuestos de un total de 12 septos, no obstante en $P$. panamensis el número de septos puede 


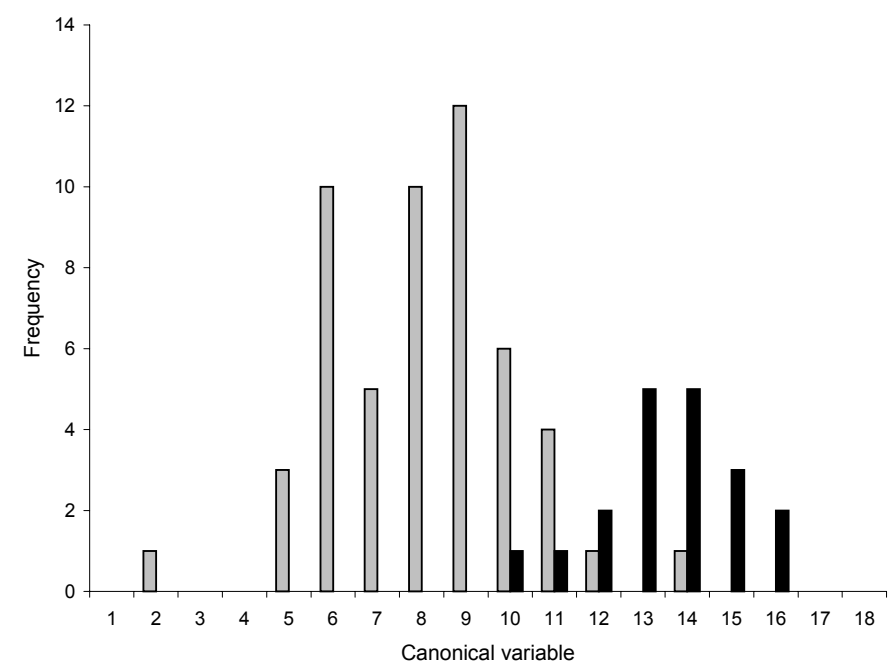

Figure 4. Results of the discriminant analysis. Histogram of frequency obtained by the mean values of the colonies in the canonical variable. Grey $=$ Porites panamensis; black $=P$. sverdrupi.

Figura 4. Resultados del análsis discriminante. Histograma de frecuencia que los valores medios de las colonias obtuvieron en la variable canónica. Gris $=$ Porites panamensis; negro $=P$. sverdrupi .

septa (NB; fig. 5e) is higher. In the western Atlantic this characteristic has been associated with decreased calcification rather than with actual forking of trabecular rows (Foster, 1986). Durham (1947) referred to this forking as "abundant perforations". As shown by its importance in the discriminant analysis (table 2), this forking has taxonomic value and is probably the most important character in the distinction of all Mexican Porites species. The only character that appears to be better developed in P. panamensis than in P. sverdrupi is wall thickness (WT; fig. 5g).

With respect to the remainder of the characters, P. panamensis displays greater morphological variation than P. sverdrupi. For example, P. panamensis usually has 5 pali, but this number varies from 2 to 7 . With regard to septa, both species have two cycles and usually a total of 12 septa, but in P. panamensis the number can fluctuate between 10 and 22. On the other hand, there are relevant differences between the frequencies of occurrence of a columella in both species. In P. sverdrupi, $2.63 \%(n=152)$ of the corallites have a columella, compared with $11.79 \%$ in P. panamensis $(n=424)$. Jameson (1997) tested the effect of using characters with missing values such as those involved in the columella development for the Belize Porites. In Jameson's work, the inclusion of columella characters in the analysis failed to distinguish between $P$. verrilli Rehberg, 1893 and P. astreoides. However the inclusion of the columella character in the present work increases the percentage $(3.77 \%)$ of correctly classified colonies of P. panamensis, the Mahalanobis distance between group centroids, and the overall performance of the entire analysis.

With qualitative or gross comparisons of corallite architecture of these species it is difficult to detect the slight
Table 2. Weighting of characters in the discriminant analysis. Correlations between the canonical variable and the original variable (COR), and standardized canonical coefficients of discriminant functions (CSFD) are given. Abbreviations for characters are explained in table 1.

Tabla 2. Importancia de los caracteres en el análisis discriminante. Correlación entre la variable canónica y la variable original (COR), y coeficientes estandarizados de las funciones discriminantes (CSFD). Las abreviaturas de los caracteres se presentan en la tabla 1.

\begin{tabular}{lcc}
\hline Character & COR & CSFD \\
\hline CD & 0.203096 & -0.37882 \\
CS & 0.117722 & 0.25918 \\
L1 & $0.446003^{*}$ & 0.30353 \\
L2 & 0.397446 & 0.45342 \\
L3 & 0.295716 & -0.64190 \\
NN & -0.031957 & 0.32423 \\
NS & -0.020065 & -0.31440 \\
NB & $0.622682^{*}$ & 0.68377 \\
PL & -0.044244 & 0.27827 \\
T1 & 0.161734 & -0.13252 \\
T2 & 0.125811 & 0.26075 \\
T3 & 0.214284 & 0.05411 \\
C1 & -0.156108 & $1.46536^{*}$ \\
C2 & -0.165866 & $-2.17567^{*}$ \\
CW & 0.194544 & 0.33699 \\
WT & $-0.405889^{*}$ & -0.71600 \\
\hline$*$ Mt &
\end{tabular}

* Most important variables

oscilar entre 10 y 22. Por otro lado, existen diferencias importantes entre ambas especies en la frecuencia de ocurrencia de la columella. En P. sverdrupi, $2.63 \%(n=152)$ de los corallites poseen columella, mientras que en $P$. panamensis $11.79 \%(n=424)$ presentan dicha característica. Jameson (1997) evaluó el efecto de usar caracteres con ausencia de valores tales como los involucrados en el desarrollo de la columella en el análisis morfológico de las especies de Porites presentes en las costas de Belice. En el trabajo desarrollado por Jameson, la inclusión de los caracteres involucrados en el desarrollo de la columella impidió la distinción entre $P$. verrilli Rehberg, 1893 y P. astreoides. Sin embargo, la inclusión de dichos caracteres en el presente trabajo, además de incrementar el porcentaje $(3.77 \%)$ de colonias de $P$. panamensis que fueron correctamente clasificadas, incrementó la distancia de Mahalanobis entre los centroides de los grupos y, en general, mejoró el resultado del análisis.

Es difícil detectar las ligeras diferencias que existen entre ambas especies mediante la comparación cualitativa o burda de la arquitectura del corallite, y probablemente esta situación sea la responsable, al menos parcialmente, de la sinonimia entre estas especies (Squires, 1959; Wells, 1983). No obstante, la forma colonial es el mejor carácter diagnostico; P. sverdrupi posee colonias ramificadas, mientras que $P$. panamensis es 
Table 3. Means ( $\pm 1 \mathrm{SE}$ ) of all corallite characters in Porites panamensis and $P$. sverdrupi. Eight corallites were measured in each colony; $n=$ number of colonies measured. ${ }^{*}$ Characters that show significant differences using a Mann-Whitney $U$ test are plotted in figure 5 .

Tabla 3. Valores medios $( \pm 1 \mathrm{SE})$ de los caracteres medidos en Porites panamensis y $P$. sverdrupi. Se midieron ocho corallites por colonia. $n=$ número de colonias medidas. ${ }^{*}$ Los caracteres que presentaron diferencias significativas luego de usar una prueba $U$ de Mann-Whitney se muestran en la figura 5 .

\begin{tabular}{lcc}
\hline Character & $\begin{array}{c}\text { P. panamensis } \\
(n=53)\end{array}$ & $\begin{array}{c}\text { P. sverdrupi } \\
(n=19)\end{array}$ \\
\hline $\mathrm{CD}^{*}$ & $1.22( \pm 0.13)$ & $1.29( \pm 0.08)$ \\
$\mathrm{CS}$ & $1.32( \pm 0.13)$ & $1.36( \pm 0.09)$ \\
$\mathrm{L} 1^{*}$ & $0.25( \pm 0.05)$ & $0.31( \pm 0.05)$ \\
$\mathrm{L} 2^{*}$ & $0.25( \pm 0.06)$ & $0.32( \pm 0.07)$ \\
$\mathrm{L} 3^{*}$ & $0.26( \pm 0.06)$ & $0.31( \pm 0.07)$ \\
$\mathrm{NN}$ & $6.41( \pm 0.29)$ & $6.39( \pm 0.28)$ \\
$\mathrm{NS}$ & $12.04( \pm 0.44)$ & $12.02( \pm 0.34)$ \\
$\mathrm{NB} *$ & $0.75( \pm 0.58)$ & $1.78( \pm 0.69)$ \\
$\mathrm{PL}$ & $5.14( \pm 0.42)$ & $5.10( \pm 0.19)$ \\
$\mathrm{T} 1$ & $0.09( \pm 0.02)$ & $0.10( \pm 0.01)$ \\
$\mathrm{T} 2$ & $0.09( \pm 0.02)$ & $0.10( \pm 0.01)$ \\
$\mathrm{T} 3 *$ & $0.09( \pm 0.02)$ & $0.10( \pm 0.01)$ \\
$\mathrm{C} 1$ & $0.01( \pm 0.03)$ & $0.01( \pm 0.01)$ \\
$\mathrm{C} 2$ & $0.01( \pm 0.02)$ & $0.01( \pm 0.01)$ \\
$\mathrm{CW}$ & $0.43( \pm 0.05)$ & $0.46( \pm 0.06)$ \\
$\mathrm{WT} *$ & $0.17( \pm 0.07)$ & $0.11( \pm 0.02)$ \\
\hline & &
\end{tabular}

differences between them, and this may have been in part responsible for their synonymy (Squires, 1959; Wells, 1983). However, colony morphology is the best diagnostic character; $P$. sverdrupi has ramose colonies, while $P$. panamensis is massive or, at most, columnar (figs. 2, 3). This difference is conservative in the studied species, and is so important from the taxonomic perspective that its use is recommended to separate species in the Indo-Pacific, where more than 20 taxa can co-exist in the same reef (Veron and Pichon, 1982; Veron 2000).

Different characters have been taken as relevant to distinguish poritid species in the Indo-Pacific and AtlanticCaribbean region. In the former, the number of pali is the main character used to discriminate species (Veron and Pichon, 1982), whereas on the east coast of the Americas, besides the number of pali, corallite diameter and columella development are important (Foster, 1986; Weil, 1992). These characters turn out to be relatively unimportant in distinguishing the two species analyzed, in which the number of bifurcate septa (NB; fig. 5e; table 2), wall thickness (WT; fig. 5g; table 2), septum dorsal length (L1; fig. 5b), and characters associated with masiva o, cuando mucho, columnar (figs. 2-3). En las especies estudiadas esta diferencia es conservativa y, al parecer, es tan importante desde la perspectiva taxonómica que es recomendada para distinguir especies en el Indo-Pacífico, donde más de 20 especies coexisten en un arrecife (Veron y Pichon, 1982; Veron, 2000).

Distintos caracteres han sido considerados como importantes para distinguir las especies de porítidos tanto en el IndoPacífico como en la región del Atlántico-Caribe. En el primero, el número de pali es el principal caracter usado para discriminar entre especies (Veron y Pichon, 1982), mientras que en la costa oriental de América, además del número de pali son importantes el diámetro del corallite y el desarrollo de la columella (Foster, 1986; Weil, 1992). Sin embargo, estos caracteres tienen poca importancia para diferenciar entre las especies estudiadas, en donde los caracteres más útiles en la determinación taxonómica son el número de septos bifurcados (NB; fig. 5e; tabla 2), el grosor de la pared (WT; fig. 5g; tabla 2), la longitud del septo dorsal (L1; fig. 5b), y los caracteres involucrados en el desarrollo de la columella (C1, C2; tabla 2).

\section{Características geográficas, ecológicas y biológicas}

Las especies poseen diferencias en su distribución batimétrica y geográfica, lo cual posiblemente tiene influencia en su ecología. Porites sverdrupi se encuentra distribuida solamente en el Golfo de California, desde Isla San José $\left(25^{\circ} \mathrm{N}\right)$ hasta Isla Ángel de la Guarda $\left(29^{\circ} \mathrm{N}\right)$ (Reyes-Bonilla, 1992; ReyesBonilla et al. 1997a), aunque en el Pleistoceno poseía una mayor distribución en la parte sur del Golfo de California (La Paz, Cerralvo y Cabo San Lucas) y al sur hasta las Islas Marías $\left(21^{\circ} \mathrm{N}\right)$ en el Pacífico mexicano (Squires, 1959). Squires (1959) reportó su presencia en las Islas Marías $\left(20^{\circ} \mathrm{N}\right)$, aunque durante los muestreos realizados en la localidad en 1999 no se registro su presencia. Reyes-Bonilla (1992) indicó que $P$. sverdrupi estaba presente en Cabo San Lucas, en el Golfo de California a principios de los ochenta, pero posteriormente las poblaciones locales se extinguieron. Esta situación es muy distinta a la que posee $P$. panamensis, la cual puede ser encontrada desde el occidente de México hasta América Central, y es tan exitosa que ha sido capaz de recolonizar las costas de Costa Rica y Panamá luego de que sus poblaciones locales fueron extintas durante El Niño 1982-1983 (Glynn, 1990; Glynn et al., 1994). Esta diferenciación geográfica apoya la hipótesis de que ambas especies son válidas, y simpátricas en una parte de su distribución.

Respecto a su distribución vertical, estas especies también poseen diferencias importantes. Squires (1959) mencionó que P. sverdrupi estaba restringida a aguas profundas $(>20 \mathrm{~m})$, mientras que $P$. panamensis era típicamente de áreas someras. Observaciones de campo demuestran que la primera especie está distribuida desde la parte intermareal (2 a $3 \mathrm{~m}$ de profundidad) en Bahía Concepción y la parte norte del Golfo de California (Reyes-Bonilla, 1992), aunque sus poblaciones son más comunes en aguas profundas. En estas localidades y otras 
columella development $(\mathrm{C} 1, \mathrm{C} 2$; table 2) are the most useful for taxonomic determinations.

\section{Geographical, ecological and biological remarks}

The species have differences in their bathymetric and geographic distribution, which quite possibly influence their ecology. Porites sverdrupi is currently distributed only in the Gulf of California, from Isla San José $\left(25^{\circ} \mathrm{N}\right)$ to Isla Ángel de la Guarda $\left(29^{\circ} \mathrm{N}\right)$ (Reyes-Bonilla, 1992; Reyes-Bonilla et al., 1997a), but in the Pleistocene it had a more widespread distribution in the southern Gulf of California (La Paz, Cerralvo, and Cabo San Lucas) and south to Islas Marías $\left(21^{\circ} \mathrm{N}\right)$, in the Mexican Pacific (Squires, 1959). Squires (1959) reported its presence at Islas Marías $\left(20^{\circ} \mathrm{N}\right)$, but surveys at that locality conducted in 1999 produced no positive record. Reyes-Bonilla (1992) indicated that $P$. sverdrupi was present south to Cabo San Lucas, in the Gulf of California, in the early 1980s, but the local populations become extinct afterwards. This situation is very different from that known for $P$. panamensis, a species that can be found from western Mexico to Central America, and that has been so successful as to be able to reintroduce itself to Costa Rica and Panama after its local populations were extirpated by the 1982-1983 El Niño (Glynn, 1990; Glynn et al., 1994). This geographic differentiation supports the hypothesis that both species are valid and sympatric in only part of their range.

Considering vertical distribution, there are also important differences. Squires (1959) suggested that $P$. sverdrupi is restricted to deep water $(>20 \mathrm{~m})$, while $P$. panamensis is typical of very shallow areas. Field observations show that the former species can occur almost in the intertidal ( 2 to $3 \mathrm{~m}$ depth) in Bahía Concepción and the northern Gulf of California (Reyes-Bonilla, 1992), although local populations are more common in deep areas. In those locations and others in the gulf, it is possible to find ramose (P. sverdrupi) and massive (P. panamensis) morphs of Porites in the same environments (Reyes-Bonilla, 1993; Reyes-Bonilla et al., 1997a), even exposed to similar conditions of light, currents or predation. Considering that the study of co-occurring colonies of different morphology is a good way to differentiate valid coral species (Veron, 1995), we do not think that the evidence supports the synonymy of $P$. sverdrupi and $P$. panamensis. Finally, another argument in favor of their separation is that branching forms in scleractinian zooxanthallate corals are not typical of deep areas, but instead, platy, massive or encrusting (Veron, 1995); hence, if $P$. sverdrupi were in fact a deep-water variety of $P$. panamensis it is difficult to explain why the former species presents that unusual form.

Regarding the biology, the polyps of $P$. sverdrupi are pale cream or colorless and difficult to observe (Squires, 1959), giving the colony a pale-white bleaching appearance through all its vertical distribution, while those of $P$. panamensis are dentro del Golfo es posible encontrar tanto la forma ramificada (P. sverdrupi) como la masiva (P. panamensis) de Porites en el mismo ambiente (Reyes-Bonilla, 1993, Reyes-Bonilla et al., 1997a), inclusive expuestas a condiciones similares de luz, corriente y depredación. Tomando en cuenta que los estudios de co-ocurrencia de colonias de diferente morfología es una herramienta poderosa para reconocer especies válidas de corales (Veron 1995), no consideramos que exista suficiente evidencia para que se mantenga la sinonimia entre $P$. sverdrupi y $P$. panamensis. Finalmente, otro argumento respecto a la validez de ambas especies es que la forma ramificada en los corales escleractinios no es típica de aguas profundas, por el contrario, las formas planas, masivas o incrustantes son más comunes (Veron, 1995); por consiguiente, si P. sverdrupi fuera la forma profunda de $P$. panamensis sería difícil explicar por qué la especie posee una forma tan inusual.

Respecto a su biología, los pólipos de $P$. sverdrupi son color crema pálido o carecen de color y son difíciles de observar (Squires, 1959), lo que le da a la colonia una apariencia pálida-blancuzca a todo lo largo de su distribución vertical; mientras que los pólipos de $P$. panamensis son de verdeamarillo a café obscuro (Veron, 2000), siendo el primer color comúnmente observado en aguas someras, mientras que el segundo es encontrado en la parte profunda. Porites sverdrupi puede ser diferenciado de $P$. panamensis por que sus colonias son pequeñas (por lo general $<15 \mathrm{~cm}$ de diámetro; las colonias grandes son poco comunes, pero cuando ocurren nunca poseen más de $30 \mathrm{~cm}$ ) (Reyes-Bonilla et al., 1997a); mientras que la talla media de $P$. panamensis es de $13 \mathrm{~cm}$ de alto y más de 30 $\mathrm{cm}$ de diámetro (Reyes-Bonilla y Calderón-Aguilera, 1994). Cuando ambas especies ocurren en bancos de rodolitos se hacen evidentes otras diferencias. Las colonias de $P$. sverdrupi no se fijan al sustrato algal, por el contrario, permanecen libres en el sustrato probablemente a consecuencia de su morfología ramificada. Por su parte, P. panamensis vive fija a algún tipo de sustrato tal como conchas de bivalvos o rodolitos vivos o muertos, a quienes frecuentemente cubren (Reyes-Bonilla et al., 1997a).

El presente trabajo concluye que $P$. sverdrupi es una especie válida y endémica del Golfo de California. Considerando que $P$. sverdrupi y $P$. panamensis poseen un registro fósil desde el Plioceno (Squires, 1959; Reyes-Bonilla, 1992) y aparentemente sobrevivieron a la extinción coralina ocurrida en el Pleistoceno (Dana, 1975; Heck y McCoy, 1978), se hace necesario preguntarnos acerca de su afinidad biogeográfica. Una comparación de las estructuras del corallite entre especies de Porites del Plioceno de Valle Imperial, California (que en ese entonces fue la parte más norteña del Golfo de California), y el Neógeno del Caribe (Budd, 1989), muestra que la hipótesis del origen común de ambas faunas no puede ser rechazada completamente. Finalmente, aunque la morfología general (forma colonial, arquitectura del corallite y dimensiones) de $P$. sverdrupi se asemeja a la de $P$. divaricata Lesueur, 1821 y a la de $P$. asteroides del Caribe, se hace necesario realizar una comparación genética y morfológica entre las especies del 

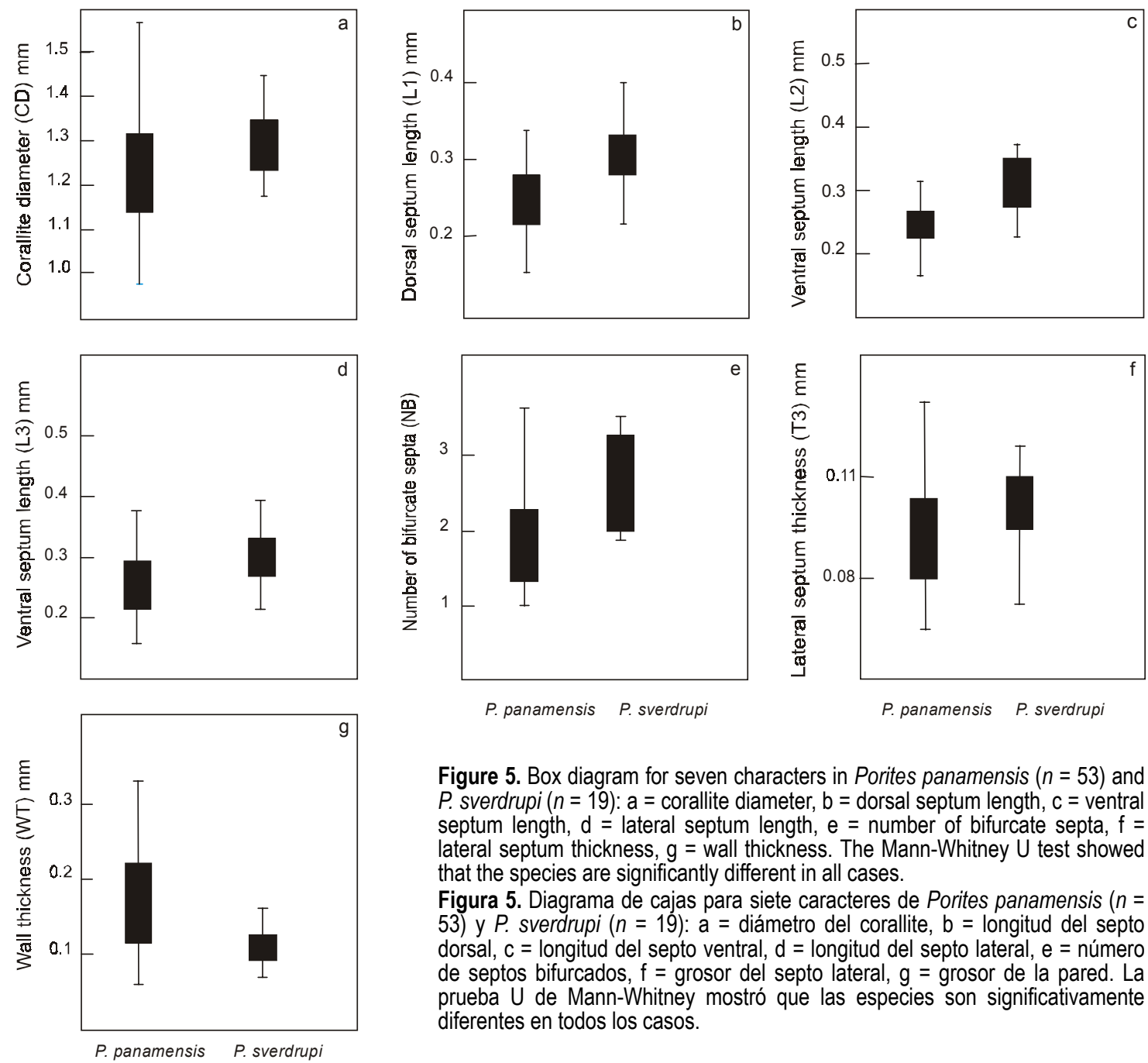

Figure 5. Box diagram for seven characters in Porites panamensis $(n=53)$ and $P$. sverdrupi $(n=19)$ : $a=$ corallite diameter, $b=$ dorsal septum length, $c=$ ventral septum length, $d=$ lateral septum length, $e=$ number of bifurcate septa, $f=$ lateral septum thickness, $g=$ wall thickness. The Mann-Whitney $U$ test showed that the species are significantly different in all cases.

Figura 5. Diagrama de cajas para siete caracteres de Porites panamensis $(n=$ 53) y $P$. sverdrupi $(n=19)$ : $a=$ diámetro del corallite, $b=$ longitud del septo dorsal, $c=$ longitud del septo ventral, $d=$ longitud del septo lateral, $e=$ número de septos bifurcados, $f=$ grosor del septo lateral, $g=$ grosor de la pared. La prueba $U$ de Mann-Whitney mostró que las especies son significativamente diferentes en todos los casos.

greenish-yellow to dark brown (Veron, 2000); the first is commonly observed in shallow waters and the second in deep waters. Porites sverdrupi can be distinguished from $P$. panamensis because its colonies are very small (most of the time $<15 \mathrm{~cm}$ in diameter; bigger ones are uncommon and never larger than $30 \mathrm{~cm}$ ) (Reyes-Bonilla et al., 1997a). The mean size of $P$. panamensis is $13 \mathrm{~cm}$ high and more than $30 \mathrm{~cm}$ in diameter (Reyes-Bonilla and Calderón-Aguilera, 1994). Other differences occur when both species coexist in rhodolith beds. Coralla of $P$. sverdrupi did not encrust algae but display a freeliving behavior, probably because of the ramose morphology. In contrast, $P$. panamensis live attached to hard substrata such as dead bivalve shells and dead or living rhodoliths, frequently overgrowing them (Reyes-Bonilla et al., 1997a).

This study concludes that $P$. sverdrupi is a valid species and endemic of the Gulf of California. Considering that $P$. sverdrupi and $P$. panamensis have occurred in the Gulf of California since the Pliocene (Squires, 1959; Reyes-Bonilla, 1992), and apparently were survivors of the mass zooxanthellate coral extinction in the Pleistocene (Dana, 1975; Heck and
Atlántico, el Pacífico oriental y el Indo-Pacífico para poder explicar totalmente el origen de la fauna coralina del Pacífico oriental tropical.

\section{Taxonomía}

Phylum Cnidaria Hatschek, 1888

Clase Anthozoa Ehrenberg, 1834

Orden Scleractinia Bourne, 1900

Familia Poritidae Gray, 1842

Genero Porites Link, 1807

Porites sverdrupi Durham, 1947

Figuras 3 y 6

Porites sverdrupi Durham, 1947: 23, fig. 4, pl. 12, fig. 2, pl. 13; Durham y Barnard 1952: 47, fig. 19, pl. 3; Squires, 1959: 420, fig. 5, pl. 33, "discusión"; Reyes-Bonilla et al., 1997a: 331. 
McCoy, 1978), this raises the question of their biogeographical origin. A comparison of corallite structure among species of Porites from the Pliocene of Imperial Valley, California (which at the time was the northernmost area of the Gulf of California), and the Neogene Caribbean (Budd, 1989) shows that the hypothesis of a common ancestry cannot be completely rejected. Finally, although gross morphology (colony form, corallite architecture, and dimensions) of $P$. sverdrupi closely resembles that of the Caribbean $P$. divaricata Lesueur, 1821 and $P$. astreoides, it is necessary to perform genetic and morphological comparisons between Atlantic, eastern Pacific and Indo-Pacific species to properly explain the origin of the eastern Pacific coral fauna.

\section{Taxonomy}

Phylum Cnidaria Hatschek, 1888

Class Anthozoa Ehrenberg, 1834

Order Scleractinia Bourne, 1900

Family Poritidae Gray, 1842

Genus Porites Link, 1807

Porites sverdrupi Durham, 1947

Figures 3 and 6

Porites sverdrupi Durham, 1947: 23, fig. 4, pl. 12, fig. 2, pl. 13; Durham and Barnard, 1952: 47, fig. 19, pl. 3; Squires, 1959: 420, fig. 5, pl. 33, “discussion"; Reyes-Bonilla et al., 1997a: 331.

\section{Material examined}

Two specimens, Isla Blanca, Baja California Sur, Mexico $\left(26^{\circ} 44^{\prime} \mathrm{N}, 111^{\circ} 52^{\prime} \mathrm{W}\right)$, MHNUABCS: 1579, 1580; one specimen, Isla Coyote, Baja California Sur, Mexico $\left(26^{\circ} 44^{\prime} \mathrm{N}\right.$, 111 $\left.{ }^{\circ} 53^{\prime} \mathrm{W}\right)$, MHNUABCS: 1578; nine specimens, Isla San José, Baja California Sur, Mexico $\left(25^{\circ} 00^{\prime} \mathrm{N}, 110^{\circ} 37^{\prime} \mathrm{W}\right)$, MHNUABCS: 751, 752, 753, 754, 755, 758, 756, 759, 775; seven specimens, El Pardito, Baja California Sur, Mexico $\left(24^{\circ} 51^{\prime} \mathrm{N}, 110^{\circ} 38^{\prime} \mathrm{W}\right)$, MHNUABCS: 1571, 1572, 1573, 1574, 1575, 1576, 1577; one specimen (type), Bahía Salinas, Isla del Carmen, Baja California Sur, Mexico, USNM M547362.

\section{Description}

Colonies highly branching. Calices $1.29 \mathrm{~mm}( \pm 0.08)$ in diameter. Corallite walls thin, $0.11 \mathrm{~mm}( \pm 0.02)$. Two septal cycles (12 septa), all equally developed. The origin of the septa, near the corallite walls, often displays evident bifurcations. Five equally developed pali flushing to surface of corallum. Columella usually wanting, or if it appears, poorly developed. All skeletal elements covered with abundant spines (fig. 6).

\section{Material examinado}

Dos especimenes, Isla Blanca, Baja California Sur, México $\left(26^{\circ} 44^{\prime} \mathrm{N}, 111^{\circ} 52^{\prime} \mathrm{W}\right)$, MHNUABCS: 1579, 1580; un espécimen, Isla Coyote, Baja California Sur, México $\left(26^{\circ} 44^{\prime} \mathrm{N}\right.$, 111 $\left.{ }^{\circ} 53^{\prime} \mathrm{W}\right)$, MHNUABCS: 1578; nueve especimenes, Isla San José, Baja California Sur, México $\left(25^{\circ} 00^{\prime} \mathrm{N}, 110^{\circ} 37^{\prime} \mathrm{W}\right)$, MHNUABCS: 751, 752, 753, 754, 755, 758, 756, 759, 775; siete especimenes, El Pardito, Baja California Sur, México $\left(24^{\circ} 51^{\prime} \mathrm{N}, 110^{\circ} 38^{\prime} \mathrm{W}\right)$, MHNUABCS: 1571, 1572, 1573, 1574, 1575, 1576, 1577; 1 espécimen (Tipo), Bahía Salinas, Isla del Carmen, Baja California Sur, México, USNM M547362.

\section{Descripción}

Colonias ramificadas. Cálices de $1.29 \mathrm{~mm}( \pm 0.08)$ de diámetro. Paredes del Corallite delgadas, $0.11 \mathrm{~mm}( \pm 0.02)$. Dos ciclos de septos (12 septos), igualmente desarrollados. El origen de los septos, cerca de la pared del corallite, regularmente presenta bifurcaciones evidentes. Cinco pali igualmente desarrollados alcanzan la superficie del corallite. Columella usualmente ausente o, si está presente, se encuentra pobremente desarrollada. Todas las estructuras se encuentran cubiertas de espinas abundantes (fig. 6).

\section{Distribución}

De Isla Ángel de la Guarda, México $\left(29^{\circ} \mathrm{N}\right)$, a Isla San José, México $\left(25^{\circ} \mathrm{N}\right)$. Islas Marías, Isla Espíritu Santo, La Paz, Isla Cerralvo, Isla San Francisco, Isla Ángel de la Guarda, Isla

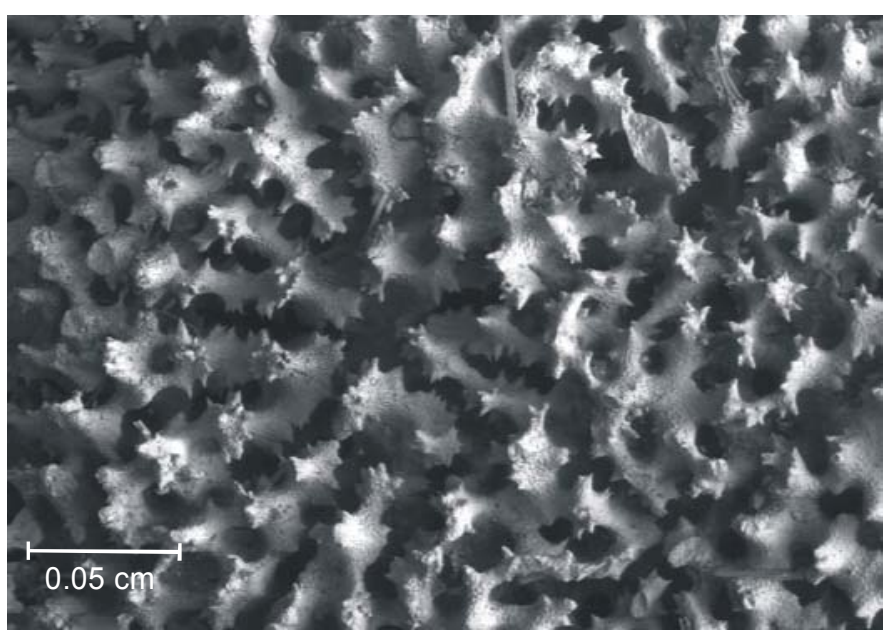

Figure 6. Electronic photography of the corallite structures of Porites sverdrupi. USNM: M547362. Recent, Bahía Salinas, Isla del Carmen, Gulf of California, Mexico. Note the abundant spines covering the skeleton. $x 40$. Figura 6. Fotografía electrónica de las estructuras del corallite en Porites sverdrupi. USNM: M547362. Reciente, Bahía Salinas, Isla del Carmen, Golfo de California, México. Note las abundantes espinas que cubren el esqueleto. x 40 . 


\section{Distribution}

From Isla Ángel de la Guarda, Mexico $\left(29^{\circ} \mathrm{N}\right)$, to Isla San José, Mexico $\left(25^{\circ} \mathrm{N}\right)$. Islas Marías, Isla Espíritu Santo, La Paz, Isla Cerralvo, Isla San Francisco, Isla Ángel de la Guarda, Isla San Marcos, Roca Lobos, Isla Partida, Isla Coronados, Isla San José, Isla del Carmen, Bahía Agua Verde, Bahía Concepción, Puerto Escondido (Squires, 1959; Reyes-Bonilla, 1992; ReyesBonilla et al., 1997a; Reyes-Bonilla and López-Pérez, 1998). Depth range: 2 to $30 \mathrm{~m}$. Although reported for Isla María Madre and Isla María Magdalena, and Islas Marías by Squires (1959), it was not recorded during intensive field searches conducted in 1999.

\section{Fossil distribution}

Pliocene: Isla Coronados, Isla del Carmen. Pleistocene: Isla San José, Isla Tiburón, Islas Marías, Isla Coronados, Isla del Carmen (Squires, 1959; Hertlein and Emerson, 1957, 1959).

\section{Type specimen}

Porites sverdrupi (USNM M547362), Bahía Salinas, Isla del Carmen, Gulf of California, Mexico.

\section{Porites panamensis Verrill, 1866}

Figures 2 and 7

Porites panamensis Verrill, 1866: 329; Bernard, 1905: 108; Reyes-Bonilla et al., 1997a: 330, fig. 3; Reyes-Bonilla et al., 1997b: 1140; Ketchum and Reyes Bonilla, 2001:730, fig. 17ab [not P. panamensis Vaughan, 1919].

Porites californica Verrill, 1870: 503-518; Bernard, 1905: 106; Durham, 1947: 20-22, figs. 3, 5-6, pl. 13, figs. 1-5,

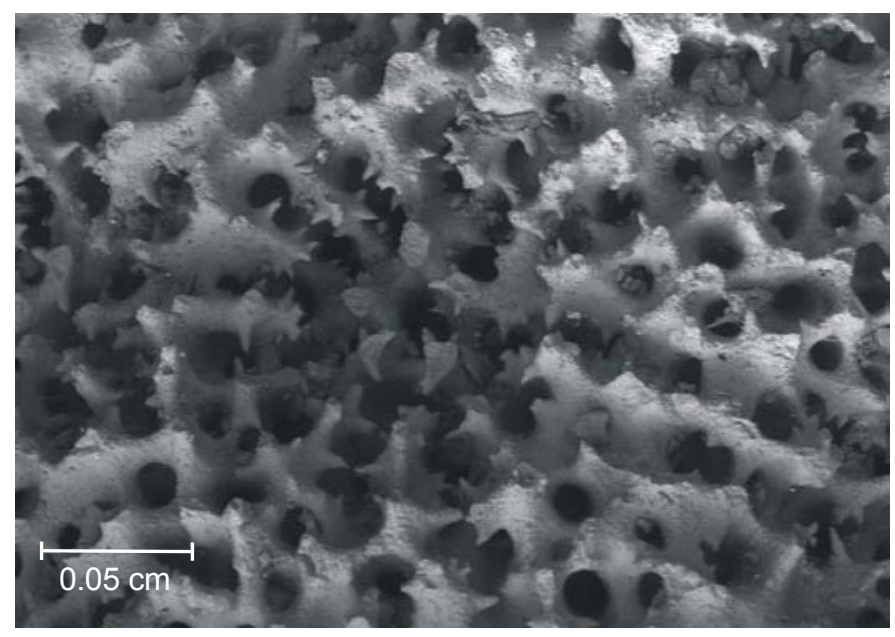

Figure 7. Electronic photography of the corallite strucures of Porites panamensis. USNM: YPM 585. Recent, Isla Perla, Gulf of Panama, Panama. x 60.

Figura 7. Fotografía electrónica de las estructuras del corallite en Porites panamensis. USNM: YPM 585. Reciente, Isla Perla, Golfo de Panamá, Panamá. x 60.
San Marcos, Roca Lobos, Isla Partida, Isla Coronados, Isla San José, Isla del Carmen, Bahía Agua Verde, Bahía Concepción, Puerto Escondido (Squires, 1959; Reyes-Bonilla, 1992; ReyesBonilla et al., 1997a; Reyes-Bonilla y López-Pérez, 1998). Rango de profundidad: 2-30 m. Aunque esta especie fue reportada en Isla María Madre e Isla María Magdalena, Islas Marías, por Squires (1959), ella no fue registrada durante búsquedas intensivas realizadas en 1999.

\section{Distribución fósil}

Plioceno: Isla Coronados, Isla del Carmen. Pleistoceno: Isla San José, Isla Tiburón, Islas Marías, Isla Coronados, Isla del Carmen (Squires, 1959; Hertlein y Emerson, 1957, 1959)

\section{Espécimen tipo}

Porites sverdrupi (USNM M547362), Bahía Salinas, Isla del Carmen, Golfo de California, México.

\section{Porites panamensis Verrill, 1866}

Figuras 2 y 7

Porites panamensis Verrill, 1866: 329; Bernard, 1905: 108; Reyes-Bonilla et al. 1997a: 330, fig. 3; Reyes-Bonilla et al., 1997b: 1140; Ketchum y Reyes Bonilla, 2001:730, figs. 17a-b [No P. panamensis Vaughan 1919].

Porites californica Verrill, 1870: 503-518; Bernard, 1905: 106; Durham, 1947: 20-22, figs. 3, 5-6. pl. 13, figs. 1-5, pl. 14; Durham y Barnard, 1952: 46, fig. 17a-b, pl. 3; Squires, 1959: 420-421, figs. 3-6, pl. 32, figs. 3-5, pl. 33; Durham, 1962: 51; Brusca, 1980: 63.

Porites nodulosa Verrill, 1870: 503-518; Bernard, 1905: 107; Durham, 1947: 22-23, figs. 1-3, pl. 12, fig. 4, pl. 13; Durham y Barnard, 1952: 46-47, fig. 18, pl. 3; Brusca, 1980: 63.

Porites porosa Verrill, 1870: 503-518; Bernard, 1905: 107.

\section{Material examinado}

Cinco especimenes, Bahía de Los Ángeles, Baja California, México $\left(28^{\circ} 55^{\prime} \mathrm{N}, 113^{\circ} 30^{\prime} \mathrm{W}\right)$, MHNUABCS: 1451, 1454 , 1456, 1463, 1467; dos especimenes, Isla Tortuga, Baja California, México $\left(27^{\circ} 27^{\prime} \mathrm{N}, 112^{\circ} 00^{\prime} \mathrm{W}\right)$, MHNUABCS: 1567,1568 ; cinco especimenes, Punta Chivato, Baja California Sur, México $\left(27^{\circ} 06^{\prime} \mathrm{N}, 111^{\circ} 57^{\prime} \mathrm{W}\right)$, MHNUABCS: 1561, 1562 , 1565, 1569, 1563; cinco especimenes, El Requesón, Baja California Sur, México $\left(26^{\circ} 38^{\prime} \mathrm{N}, 111^{\circ} 50^{\prime} \mathrm{W}\right)$, MHNUABCS: 1480, 1484, 1501, 1508, 1513; cinco especimenes, El Bajo, Baja California Sur, México $\left(26^{\circ} 06^{\prime} \mathrm{N}, 111^{\circ} 20^{\prime} \mathrm{W}\right)$, MHNUABCS: 1531, 1538, 1544, 1546, 1558; cinco especimenes, Isla San José, Baja California Sur, México $\left(25^{\circ} 00^{\prime} \mathrm{N}\right.$, $\left.110^{\circ} 37^{\prime} \mathrm{W}\right)$, MHNUABCS: 760, 761, 762, 766, 768; cuatro especimenes, La Catedral (Isla Espíritu Santo), Baja California Sur, México $\left(24^{\circ} 25^{\prime} \mathrm{N}, 110^{\circ} 21^{\prime} \mathrm{W}\right)$, MHNUABCS: 868, 869, 
pl. 14; Durham and Barnard, 1952: 46, fig. 17a-b, pl. 3; Squires, 1959: 420-421, figs. 3-6, pl. 32, figs. 3-5, pl. 33; Durham, 1962: 51; Brusca, 1980: 63.

Porites nodulosa Verrill, 1870: 503-518; Bernard, 1905: 107; Durham, 1947: 22-23, figs. 1-3, pl. 12, fig. 4, pl. 13; Durham and Barnard, 1952: 46-47, fig. 18, pl. 3; Brusca, 1980: 63.

Porites porosa Verrill, 1870: 503-518; Bernard, 1905: 107.

\section{Material examined}

Five specimens, Bahía de Los Ángeles, Baja California, Mexico $\left(28^{\circ} 55^{\prime} \mathrm{N}, 113^{\circ} 30^{\prime} \mathrm{W}\right)$, MHNUABCS: 1451, 1454, 1456, 1463, 1467; two specimens, Isla Tortuga, Baja California, Mexico $\left(27^{\circ} 27^{\prime} \mathrm{N}, 112^{\circ} 00^{\prime} \mathrm{W}\right)$, MHNUABCS: 1567, 1568; five specimens, Punta Chivato, Baja California Sur, Mexico $\left(27^{\circ} 06^{\prime} \mathrm{N}, 111^{\circ} 57^{\prime} \mathrm{W}\right)$, MHNUABCS: $1561,1562,1565,1569$, 1563; five specimens, El Requesón, Baja California Sur, Mexico $\left(26^{\circ} 38^{\prime} \mathrm{N}, 111^{\circ} 50^{\prime} \mathrm{W}\right)$, MHNUABCS: 1480, 1484 , 1501, 1508, 1513; five specimens, El Bajo, Baja California Sur, Mexico $\left(26^{\circ} 06^{\prime} \mathrm{N}, 111^{\circ} 20^{\prime} \mathrm{W}\right)$, MHNUABCS: 1531, 1538, 1544, 1546, 1558; five specimens, Isla San José, Baja California Sur, Mexico $\left(25^{\circ} 00^{\prime} \mathrm{N}, 110^{\circ} 37^{\prime} \mathrm{W}\right)$, MHNUABCS: 760, 761, 762, 766, 768; four specimens, La Catedral (Isla Espíritu Santo), Baja California Sur, Mexico $\left(24^{\circ} 25^{\prime} \mathrm{N}\right.$, $\left.110^{\circ} 21^{\prime} \mathrm{W}\right)$, MHNUABCS: $868,869,870,871$; five specimens, Bahía San Gabriel (Isla Espíritu Santo), Baja California Sur, Mexico $\left(24^{\circ} 25^{\prime} \mathrm{N}, 110^{\circ} 21^{\prime} \mathrm{W}\right)$, MHNUABCS: 597, 598, 599, 601, 859; two specimens, Isla Gaviota, Baja California Sur, Mexico $\left(24^{\circ} 17^{\prime} \mathrm{N}, 110^{\circ} 21^{\prime} \mathrm{W}\right)$, MHNUABCS: 665, 666; one specimen, Isla Cerralvo, Baja California Sur, Mexico $\left(24^{\circ} 15^{\prime} \mathrm{N}\right.$, $\left.110^{\circ} 22^{\prime} \mathrm{W}\right)$, MHNUABCS: 929; four specimens, Punta Pericos, Baja California Sur, Mexico $\left(24^{\circ} 02^{\prime} \mathrm{N}, 109^{\circ} 49^{\prime} \mathrm{W}\right)$, MHNUABCS: 635, 636, 637, 638; five specimens, Cabo Pulmo, Baja California Sur, Mexico $\left(23^{\circ} 26^{\prime} \mathrm{N}, 109^{\circ} 25^{\prime} \mathrm{W}\right)$, MHNUABCS: 1254, 1255, 1256, 1257, 1258; five specimens, Bahía Chileno, Baja California Sur, Mexico $\left(22^{\circ} 56^{\prime} \mathrm{N}\right.$, $\left.109^{\circ} 48^{\prime} \mathrm{W}\right)$, MHNUABCS: 1320, 1326, 1327, 1394, 1321; one specimen (type), Pearl Island, Gulf of Panama, Panama $(P$. panamensis YPM 585); one specimen (type), La Paz, Baja California Sur, Mexico (P. californica YPM 1599); one specimen (type), La Paz, Baja California Sur, Mexico (P. nodulosa YPM 6844a); one specimen (type), La Paz, Baja California Sur, Mexico (P. porosa YPM 4068).

\section{Description}

Colonies massive or encrusting, having an undulated surface or lobes that sometimes extend as columnar expansions, short and rounded at the top (fig. 2). Calices average $1.22 \mathrm{~mm}$ $( \pm 0.13)$ in diameter. Corallites have porous thick walls $0.17 \mathrm{~mm}( \pm 0.06)$ in width. Two cycles of septa, usually producing corallites with 12 septa, although they can display between 22 and 10. Lateral, dorsal and ventral septa equally developed. Usually 5 equally developed pali, but the number
870, 871; cinco especimenes, Bahía San Gabriel (Isla Espíritu Santo), Baja California Sur, México $\left(24^{\circ} 25^{\prime} \mathrm{N}, 110^{\circ} 21^{\prime} \mathrm{W}\right)$, MHNUABCS: 597, 598, 599, 601, 859; dos especimenes, Isla Gaviota, Baja California Sur, México $\left(24^{\circ} 17^{\prime} \mathrm{N}, 110^{\circ} 21^{\prime} \mathrm{W}\right)$, MHNUABCS: 665, 666; un espécimen, Isla Cerralvo, Baja California Sur, México $\left(24^{\circ} 15^{\prime} \mathrm{N}, 110^{\circ} 22^{\prime} \mathrm{W}\right)$, MHNUABCS: 929; cuatro especimenes, Punta Pericos, Baja California Sur, México $\left(24^{\circ} 02^{\prime} \mathrm{N}, 109^{\circ} 49^{\prime} \mathrm{W}\right)$, MHNUABCS: 635, 636, 637, 638; cinco especimenes, Cabo Pulmo, Baja California Sur, México $\left(23^{\circ} 26^{\prime} \mathrm{N}, 109^{\circ} 25^{\prime} \mathrm{W}\right)$, MHNUABCS: 1254, 1255, 1256, 1257, 1258; cinco especimenes, Bahía Chileno, Baja California Sur, México $\left(22^{\circ} 56^{\prime} \mathrm{N}, 109^{\circ} 48^{\prime} \mathrm{W}\right)$, MHNUABCS: 1320, 1326, 1327, 1394, 1321; un espécimen (tipo), Isla Perla, Golfo de Panamá, Panamá (P. panamensis YPM 585); un espécimen (tipo), La Paz, Baja California Sur, México (P. californica YPM 1599); un espécimen (tipo), La Paz, Baja California Sur, México (P. nodulosa YPM 6844a); un espécimen (tipo), La Paz, Baja California Sur, México (P. porosa YPM 4068).

\section{Descripción}

Colonias masivas o incrustantes; poseen una superficie ondulada o lóbulos que, a veces, se extienden a manera de columnas, mismas que son cortas y redondeadas en la punta (fig. 2). Los cálices poseen un diámetro medio de $1.22 \mathrm{~mm}$ $( \pm 0.13)$. Los corallites poseen una pared porosa y gruesa 0.17 $\mathrm{mm}( \pm 0.06)$. Poseen dos ciclos de septos, regularmente con 12 septos, aunque pueden presentar entre 10 y 22 . Los septos lateral, dorsal y ventral están igualmente desarrollados. Usualmente poseen cinco pali igualmente desarrollados, el número puede variar entre cinco y siete, pero algunas veces solo presentan 2 o 3. los pali usualmente no alcanzan la superficie del corallite. Columella rudimentaria, esponjosa, pobremente desarollada y regularmente ausente.

\section{Distribución}

De San Felipe $\left(30^{\circ} \mathrm{N}\right)$, Golfo de California, México, a Isla Gorgona, Colombia $\left(3^{\circ} \mathrm{N}\right)$. Además en Bahía Magdalena, en la costa oeste de la Península de Baja California $\left(24^{\circ} \mathrm{N}\right)$. Bahía Concepción, Isla Margarita, Isla del Carmen, Isla Tiburón, San Luis Gonzaga, Isla Coronado, Bahía Las Ánimas, Guaymas, Isla San Marcos, Isla Magdalena, Bahía Santa Inés, Santa Rosalía, Bahía Concepción, Isla San José, La Paz, Isla Espíritu Santo, Isla Ángel de la Guarda, Bahía Agua Verde, Puerto Peñasco, Isla Montserrat, Cabo Pulmo, Los Frailes, Isla Cerralvo. En el Pacífico mexicano: Islas Marías, Islas Revillagigedo, Baja California, Baja California Sur, Sonora, Sinaloa, Nayarit, Jalisco, Colima, Guerrero y Oaxaca (Verrill, 1868, Durham, 1947, Squires, 1959, Reyes-Bonilla y LópezPérez, 1998; Reyes-Bonilla et al., en prensa). En Centroamérica: Sámara, Cabo Blanco, Bahía Culebra, Isla del Caño, Isla de Coco (Costa Rica); Golfo de Chiriquí, Golfo de Panamá, Isla Secas, Isla Perlas, Isla Naranjas, Isla Coiba, Isla 
can vary from 5 to 7 , and sometimes only 2 or 3 . Pali do not commonly reache the corallite surface. Columella rudimentary, spongy, poorly developed and often wanting.

\section{Distribution}

From San Felipe $\left(30^{\circ} \mathrm{N}\right)$, Gulf of California, Mexico, to Isla Gorgona, Colombia $\left(3^{\circ} \mathrm{N}\right)$. Also Bahía Magdalena, on the west coast of the Baja California Peninsula $\left(24^{\circ} \mathrm{N}\right)$. Bahía Concepción, Isla Margarita, Isla del Carmen, Isla Tiburón, San Luis Gonzaga, Isla Coronado, Bahía las Ánimas, Guaymas, Isla San Marcos, Isla Magdalena, Bahía Santa Inés, Santa Rosalía, Bahía Concepción, Isla San José, La Paz, Isla Espíritu Santo, Isla Ángel de la Guarda, Bahía Agua Verde, Puerto Peñasco, Isla Montserrat, Cabo Pulmo, Los Frailes, Isla Cerralvo. In the Mexican Pacific: Islas Marías, Islas Revillagigedo, Baja California, Baja California Sur, Sonora, Sinaloa, Nayarit, Jalisco, Colima, Guerrero and Oaxaca (Verrill, 1868; Durham, 1947; Squires, 1959; Reyes-Bonilla and López-Pérez, 1998; Reyes-Bonilla et al., in press). In Central America: Sámara, Cabo Blanco, Bahía Culebra, Isla del Caño, and Isla de Coco in Costa Rica; Golfo de Chiriquí, Gulf of Panama, Isla Secas, Isla Perlas, Isla Naranjas, Isla Coiba, Isla Contreras, and Isla Iguana in Panama; Isla Gorgona, Colombia (Glynn and Ault, 2000). Depth range: 0 to $30 \mathrm{~m}$.

\section{Fossil distribution}

Pliocene: Isla del Carmen, Isla Cerralvo, Isla Coronados. Pleistocene: Isla Tiburón, Isla del Carmen, San Marcos, Bahía Magdalena, Islas Marías, Oaxaca, Mulegé, La Paz (Palmer, 1928; Squires, 1959; Hertlein and Emerson, 1957; ReyesBonilla, 1992).

\section{Type specimens}

Porites panamensis (YPM 585), Pearl Island, Gulf of Panama, Panama; P. californica (YPM 1599), La Paz, Baja California Sur, Mexico; P. nodulosa (YPM 6844a), La Paz, Baja California Sur, Mexico; P. porosa (YPM 4068), La Paz, Baja California Sur, Mexico.

\section{Acknowledgements}

We thank Luis Herrera (director) of the Museo de Historia Natural de la Universidad Autónoma de Baja California at La Paz, Mexico, for access to the material under their care. Stephen D. Cairns (National Museum of Natural History, Smithsonian Institution) and Eric Lazo (Yale Peabody Museum of Natural History) lent the type specimens of Porites that were analyzed in this paper. Funding was provided by a fellowship to the first author from the Consejo Nacional de Ciencia y Tecnología (CONACYT, Mexico), and by Comisión Nacional
Contreras, Isla Iguana (Panamá); Isla Gorgona, Colombia (Glynn y Ault, 2000). Rango de profundidad: 0-30 m.

\section{Distribución fósil}

Plioceno: Isla del Carmen, Isla Cerralvo, Isla Coronados. Pleistoceno: Isla Tiburón, Isla del Carmen, San Marcos, Bahía Magdalena, Islas Marías, Oaxaca, Mulegé y La Paz (Palmer, 1928, Squires, 1959, Hertlein y Emerson, 1957, Reyes-Bonilla, 1992).

\section{Espécimen tipo}

Porites panamensis (YPM 585), Isla Perla, Golfo de Panamá, Panamá; P. californica (YPM 1599), La Paz, Baja California Sur, México; P. nodulosa (YPM 6844a), La Paz, Baja California Sur, México; P. porosa (YPM 4068) La Paz, Baja California Sur, México.

\section{Agradecimientos}

Agradecemos a Luis Herrera, director del Museo de Historia Natural de la Universidad Autónoma de Baja California Sur, en La Paz, México, por permitirnos el acceso al material. Stephen D. Cairns (Museo Nacional de Historia Natural, Instituto Smithsoniano) y Eric Lazo (Museo Peabody de Historia Natural) facilitaron los especimenes tipo de Porites que fueron analizados en esta contribución. Los fondos para la realización de este trabajo fueron proveídos mediante una beca otorgada al primer autor por el Consejo Nacional de Ciencia y Tecnología de México (CONACYT), y por la Comisión Nacional para el Conocimiento y Uso de la Biodiversidad (Proyecto FB342/H337/96, a HRB). Agradecemos a John Dawson (Universidad de Iowa) y Gerardo Leyte (Universidad del Mar) por los comentarios y sugerencias al manuscrito.

Traducido al español por los autores.

para el Conocimiento y Uso de la Biodiversidad (project FB342/H337/96, to HRB). We thank John Dawson (University of Iowa) and Gerardo Leyte (Universidad del Mar) for their comments and suggestions to the manuscript.

\section{References}

Amaral, F.D. (1994). Morphological variation in the reef coral Montastraea cavernosa in Brazil. Coral Reefs, 13: 113-117.

Ayre, D.J., Veron, J.E.N. and Dufty, S.L. (1991). The corals Acropora palifera and Acropora cuneata are genetically and ecologically distinct. Coral Reefs, 10: 13-18.

Bernard, H.M. (1905). Porites of the Indo-Pacific region. In: H.M Bernard (ed.), Catalogue of Madreporarian Corals in the British Museum, London, pp. 1-206.

Brakel, W.H. (1977). Corallite variation in the Porites and the species problem in corals. Proc. 3rd Int. Coral Reef Symp., Miami, 1: $457-462$. 
Brusca, R.C. (1980). Common Intertidal Invertebrates of the Gulf of California. Univ. Arizona Press, Arizona, 513 pp.

Budd, A.F. (1988). Large-scale evolutionary patterns in the reef-coral Montastraea: The role of phenotypic plasticity. Proc. 6th Int. Coral Reef Symp., Townsville, 3: 393-398.

Budd, A.F. (1989). Biogeography of Neogene Caribbean reef corals and its implications for the ancestry of eastern Pacific reef-corals. Mem. Assoc. Australasian Paleontologist, 8: 219-230.

Budd, A.F. (1993). Variation within and among morphospecies of Montastraea. Cour Fors Sencken, 164: 241-254.

Budd, A.F. and Coates, A.G. (1992). Nonprogressive evolution in a clade of Cretaceous Montastraea-like corals. Paleobiology, 18: 425-446.

Dana, T.D. (1975). Development of contemporary eastern Pacific coral reefs. Mar. Biol., 33: 355-374.

Durham, J.W. (1947). Corals from the Gulf of California and the north Pacific coast of America. Mem. Geol. Soc. Am., 20: 1-68.

Durham, J.W. (1962). Corals from the Galapagos and Cocos Islands. Proc. Calif. Acad. Sci., 4th Ser., 32: 41-56.

Durham, J.W. and Barnard, J. L. (1952). Stony corals of the eastern Pacific collected by the Velero III and Velero IV. Allan Hancok Pac. Exped., 16: 1-110.

Foster, A.B. (1979a). Environmental variation in a fossil scleractinian coral. Lethaia, 12: 245-264.

Foster, A.B. (1979b). Phenotypic plasticity in the reef corals Montastraea annularis (Ellis and Solander) and Siderastrea siderea (Ellis and Solander). J. Exp. Mar. Biol. Ecol., 39: 25-54.

Foster, A.B. (1980a). Ecology and morphology of the Caribbean Mio-Pliocene reef-coral Siderastrea. Acta Palaeontol. Pol., 25: 439-450.

Foster, A.B. (1980b). Environmental variation in skeletal morphology within the Caribbean reef corals Montastrea annularis and Siderastrea siderea. Bull. Mar. Sci., 30: 678-709.

Foster, A.B. (1984). The species concept in the fossil hermatypic corals: A statistical approach. Palaeontogr. Americana, 54: 58-69.

Foster, A.B. (1985). Variation within coral colonies and its importance for interpreting fossil species. J. Paleontol., 59: 1359-1381.

Foster, A.B. (1986). Neogene paleontology in the northern Dominican Republic. 3. The family Poritidae (Anthozoa: Scleractinia). Bull. Am. Paleontol., 90: 45-123.

Garthwaite, R.L., Potts, D.C., Veron, J.E.N. and Done, T. J. (1994). Electrophoretic identification of Poritid species (Anthozoa: Scleractinia). Coral Reefs, 13: 49-56.

Grewingk, C. (1848). Beitrag zur Kenntniss der geognostischen Beschaffenheit Californiens. Verhandl Russisch Min Gesell St. Petersburg, 1847: 142-162.

Glynn, P.W. (1990). Coral mortality and disturbances to coral reefs in the tropical eastern Pacific. In: P.W. Glynn (ed.), Global Ecological Consequences of the 1982-83 El Niño Southern Oscillation. Elsevier Oceanographic Series, 52, pp 55-126.

Glynn, P.W. (1997). Eastern Pacific reef coral biogeography and faunal flux: Durham's dilemma revisited. Proc. 8th Int. Coral Reef Symp., Panama, 1: 371-378.

Glynn, P.W and Ault, J.S. (2000). A biogeographic analysis and review of the far eastern Pacific coral reef region. Coral Reefs, 19: $1-23$.

Glynn, P.W., Colley, S.B., Eakin, C.M., Smith, D.B., Gassman, N.J., Guzmán, H.M., del Rosario, J.B. and Maté, J.L. (1994). Reef coral reproduction in the eastern Pacific: Costa Rica, Panama and Galapagos Islands (Ecuador). Part II. Poritidae. Mar. Biol., 118: 191-208.

Heck, K.L Jr. and McCoy, E.D. (1978). Long-distance dispersal and the reef-building corals of the eastern Pacific. Mar. Biol., 48: $349-356$.
Hertlein, L.G and Emerson, W.K. (1957). Additional notes on the invertebrate fauna of Clipperton Island. Am. Mus. Novit., 1859: $1-9$.

Hertlein, L.G and Emerson, W.K. (1959) Pliocene and Pleistocene megafossils from the Tres Marías Islands. Am. Mus. Novit., 1940: $1-15$.

Hodgson, G. (1995). Corales pétreos marinos (tipo Cnidaria, orden Scleractinia). En: W. Fischer., F. Krupp., W. Scheider., C. Sommer., K.E. Carpenter y V.H. Niem (eds.), Guia FAO para la Identificación de Especies para los Fines de la Pesca. Algas e Invertebrados. FAO, Roma, pp. 83-97.

Jameson, S.C. (1997). Morphometric analysis of the Poritidae (Anthozoa: Scleractinia) of Belize. Proc. 8th Int. Coral Reef Symp., Panama, 2: 1591-1596.

Ketchum, J.T. y Reyes-Bonilla, H. (2001). Taxonomía y distribución de los corales hermatípicos (Scleractinia) del Archipiélago de Revillagigedo, Pacífico de México. Rev. Biol. Trop., 49(3-4): 803-848.

Knowlton, N., Weil, E., Weigt, L.A. and Guzman, H.M. (1992). Sibling species in Montastraea annularis, coral bleaching and the coral climate record. Science, 225: 330-333.

Lasker, H.R. (1981). Phenotypic variation in the coral Montastraea cavernosa and its effects on colony energetics. Biol. Bull., 160: 292-302.

Palmer, R.H. (1928). Fossils and recent corals and coral reefs of western Mexico. Proc. Am. Philosophical Soc. Philadelphia, 67: 21-37.

Potts, D.C., Budd, A.F. and Garthwaite, R.L. (1993). Soft tissue $v s$ skeletal approaches to species recognition and phylogeny reconstruction in corals. Cour Forsch Institute Senck, 164: 221-231.

Reyes-Bonilla, H. (1992). New records for hermatypic corals (Anthozoa: Scleractinia) in the Gulf of California, Mexico, with an historical and biogeographical discussion. J. Nat. Hist., 26: $1163-1175$.

Reyes-Bonilla, H. (1993). Biogeografía y ecología de los corales hermatípicos (Anthozoa: Scleractinia) del Pacífico de México. En: S. Salazar-Vallejo y N.E. González (eds.), Biodiversidad Marina y Costera de México. CONABIO/CIQRO, Chetumal, pp. 207-222.

Reyes-Bonilla, H. (2002). Checklist of valid names and synonyms of stony corals (Anthozoa: Scleractinia) from the eastern Pacific. J. Nat. Hist., 36: 1-13.

Reyes-Bonilla, H. y Calderón-Aguilera, L.E. (1994). Parámetros poblacionales de $P$. panamensis (Anthozoa: Scleractinia) en el arrecife de Cabo Pulmo, México. Rev. Biol. Trop., 42: 121-128.

Reyes-Bonilla, H. y López-Pérez, R.A. (1998). Biogeografía de los corales pétreos (Scleractinia) del Pacífico de México. Cienc. Mar., 24: 211-224.

Reyes-Bonilla, H. and Carricart-Ganivet, J.P. (2000). Porites arnaudi, a new species of stony coral (Anthozoa: Scleractinia: Poritidae) from oceanic islands of the eastern Pacific Ocean. Proc. Biol. Soc. Washington, 113: 561-571.

Reyes-Bonilla, H., Riosmena-Rodríguez, R. and Foster, M.S. (1997a). Hermatypic corals associated with rhodolith beds in the Gulf of California, Mexico. Pac. Sci., 3: 328-337.

Reyes-Bonilla, H., Duarte, F.S. y Cobarrubias, O.A. (1997b). Gorgonias y corales pétreos (Anthzoa: Gorgonacea y Scleractinia) de Cabo Pulmo, México. Rev. Biol. Trop., 45: 1439-1443.

Reyes-Bonilla, H., Cruz-Piñon, G. y López-Perez, R.A. Lista sistemática, sinonimias y distribución de los corales pétreos (Anthozoa: Scleractinia) del Pacífico Mexicano. Hidrobiologica, (en prensa).

Squires, D.R. (1959). Corals and coral reefs in the Gulf of California. Bull. Am. Mus. Nat. Hist., 118: 370-431.

Veron, J.E.N. (1995). Corals in Space and Time. Comstock/Cornell, Ithaca, $321 \mathrm{pp}$. 
Veron, J.E.N. (2000). Corals of the World. Vols. 1-3. Australian Institute of Marine Science, Townsville, $1382 \mathrm{pp}$.

Veron, J.E.N and Pichon, M. (1982). Scleractinia of eastern Australia. Part IV. Family Poritidae. Aust. Inst. Mar. Sci. Monogr. Ser., 5: 1159.

Verrill, A.E. (1864). List of the polyps and corals sent by the Museum of Comparative Zoology to other institutions in exchange, with annotations. Bull. Mus. Comp. Zool. Harvard, 1: 29-60.

Verrill, A.E. (1866). On the polyps and corals of Panama with descriptions of new species. Proc. Boston Soc. Nat. Hist., 10: 325-357.

Verrill, A.E. (1868-1870). Review of the corals and polyps of the west coast of America. Trans. Connecticut Acad. Arts Sci., 1: 377-558.
Verrill, A.E. (1869). Synopsis of the polyps and corals of the North Pacific Exploring Expedition. Madreporaria. Proc. Essex Inst., 6: 83-100.

Weil, E. (1992). Genetic and morphological variation in Caribbean and Eastern Pacific Porites (Anthozoa: Scleractinia). Preliminary results. Proc, 7th Int. Coral Reef Symp., Guam, 2: 643-656.

Wells, J.W. (1983). Annotated list of the scleractinian corals of the Galapagos Islands. In: P.W. Glynn and G.M. Wellington (eds.), Corals and Coral Reefs of the Galapagos Islands. Univ. California Press, Berkeley, pp. 212-295.

Zar, J.H. (1996). Biostatistical Analysis. Prentice Hall, New Jersey, $929 \mathrm{pp}$. 